\title{
Total Reflection X-Ray Fluorescence Spectroscopy (TXRF) Method Validation: Determination of Heavy Metals in Dietary Supplements
}

\author{
Blanca G. Beltrán $\left(\mathbb{D},{ }^{1}\right.$ Victor Ramos-Sanchez $(\mathbb{D}),{ }^{2}$ David Chávez-Flores $\left(\mathbb{D},{ }^{2}\right.$ \\ Rogelio Rodríguez-Maese $\mathbb{D}^{3},{ }^{3}$ and Edwin Palacio ${ }^{4}{ }^{4}$ \\ ${ }^{1}$ Faculty of Nursing and Nutriology, Chihuahua Autonomous University, Chihuahua 31125, Mexico \\ ${ }^{2}$ Faculty of Chemical Sciences, Chihuahua Autonomous University, Chihuahua 31125, Mexico \\ ${ }^{3}$ Environment and Energy Department, Advances Materials Research Center (CIMAV) S.C, Miguel de Cervantes 120, \\ Chihuahua 31109, Mexico \\ ${ }^{4}$ Laboratory of Environmental Analytical Chemistry, University of the Balearic Islands, \\ Cra. Valldemossa km 7’5 Palma de Mallorca, Palma, Spain \\ Correspondence should be addressed to Blanca G. Beltrán; bbeltran@uach.mx
}

Received 3 September 2020; Revised 4 November 2020; Accepted 9 November 2020; Published 3 December 2020

Academic Editor: Arturo Espinosa Ferao

Copyright (c) 2020 Blanca G. Beltrán et al. This is an open access article distributed under the Creative Commons Attribution License, which permits unrestricted use, distribution, and reproduction in any medium, provided the original work is properly cited.

\begin{abstract}
Dietary supplements may contain heavy metals with the property of bioaccumulation in humans. The aim of this research was to validate and apply two analytical methods to determine $\mathrm{Pb}, \mathrm{As}, \mathrm{Cr}$, and $\mathrm{Hg}$ in dietary supplements by Total Reflection X-ray Fluorescence Spectroscopy (TXRF). Methods validation was conducted through a multivariate analysis using a central composite design (CCD) and a desirability function. Critical values for each study variable were established. The TXRF_DS_1 method was proposed for $\mathrm{Pb}, \mathrm{As}$, and $\mathrm{Cr}$ determinations, while the TXRF_DS_2 was established for Hg analysis. The digestion method with an acid mixture $\left(\mathrm{HNO}_{3}+\mathrm{HCl}+\mathrm{H}_{2} \mathrm{O}_{2}\right)$ was used to break down the organic material of dietary supplements. A solution of $10 \mu \mathrm{g} \mathrm{L}$ Ga was used as an internal standard. Excellent analytical performance was obtained as LODs of $0.59,0.41,0.57$, and $0.75 \mu \mathrm{g} \mathrm{L}$ and LOQs of $1.95,1.35,1.90$, and $2.50 \mu \mathrm{gL}^{-1}$ for $\mathrm{Pb}, \mathrm{As}$, $\mathrm{Cr}$, and $\mathrm{Hg}$, respectively. Calibration curves showed a good linearity for all elements $\left(R^{2}>0.999\right)$. Excellent accuracy and precision in measurements (\% RSD) was achieved. The real and spiked samples analysis demonstrated the applicability of the TXRF technique (percentage recovery 91-108\%). Besides, two samples were analyzed in a comparison study between the TXRF_DS_1 method and the ICP-OES method. The results obtained showed good agreement between both techniques. The TXRF technique allows the analysis of toxic heavy metals in dietary supplements, which are marketed in a wide variety of presentations.
\end{abstract}

\section{Introduction}

Dietary supplements are products that contain a "dietary ingredient" which includes vitamins, minerals, and amino acids, as well as other substances that can be used to supplement the diet [1]. They can be prepared from decoctions from fresh or dried crude herbs from algae or plants, but are usually made into different presentations, including powders, tablets, capsules, energy bars, and liquids [2]. The consumers believe that since these products contain ingredients that come from plants, they are safe and without any adverse effect [3]. However, many ingredients are derived from natural products, which can be toxic due to the presence of heavy metals.

Dietary supplements could contain heavy metals due two fundamental reasons. (a) Their distribution is not uniform, such that some soils may contain higher concentrations derived from natural components or geological sources as well as from human activities or anthropogenic causes. Taken up by plants, heavy metals may enter the food chain in 
significant amounts. Hence, people could be at risk of adverse health effects from consuming dietary supplements made with plants grown in soils containing elevated metal concentrations [4]. (b) Contamination may occur during the production processes (manufacturing, handling, storage, processing, or distribution). Heavy metals such as $\mathrm{Pb}$, As, $\mathrm{Hg}$, and $\mathrm{Cr}$ are most commonly the subject of attention in manufacturing dietary supplements $[4,5]$.

The botanical ingredients in dietary supplements may contain elevated concentrations of As, contributing to the overall exposure to this element [5]. Arsenic exposure affects all organ systems, including the cardiovascular, dermatologic, nervous, renal, gastrointestinal, and respiratory systems. Also, it is now well accepted that exposure to high levels is associated with an increased risk of various types of cancers, most notably, skin, urinary bladder, and lung [6].

Lead is poisonous to humans and can affect people of any age or health status. Lead is especially harmful to vulnerable populations, including infants, young children, pregnant women, and their fetuses, and others with chronic health conditions [7]. On the other hand, $\mathrm{Pb}$ poisoning mainly affects the nervous system (headache, decreased attention span, irritability, loss of memory, and dullness are the early symptoms) [8].

Chromium is a mineral nutrient that is essential for the proper functioning of many systems in the human body. Some studies have observed that $\mathrm{Cr}$ (III) could improve insulin action, but the relation between $\mathrm{Cr}$ and insulin is not well known. This element also could participate in lipid metabolism and could have some effect on body composition [9]. The major problem with some dietary supplements is that their labels do not show the concentration of either the oxidation estate of $\mathrm{Cr}$. The oxidation state should consider when evaluating the toxicity of $\mathrm{Cr}$ compounds. Due to this, metal may form complexes with peptides, proteins, and DNA, resulting in DNA-protein cross-links, DNA strand breaks, and alterations in cellular signaling pathways, which may contribute to the toxicity and carcinogenicity of chromium compounds. Meanwhile, the products of metabolic reduction of $\mathrm{Cr}(\mathrm{VI})$ (free radicals and $\mathrm{Cr} \mathrm{IV}$ and V), and the newly generated $\mathrm{Cr}$ (III), are thought to be in part responsible for the carcinogenic effects seen in human and animal studies [10].

Abdulla et al. presented reports of mercury contamination of dietary supplements [11]. Mercury interferes with many enzymatic reactions, causes problems in migration and division of cells, and is responsible for cell damage, or even death [12].

Heavy metals, even at trace levels, are very harmful to human beings. Thus, their analytical determination is a very critical and essential topic, which has attracted considerable attention [7], particularly due to the actual amount of $\mathrm{Pb}, \mathrm{As}$, $\mathrm{Cr}$, and $\mathrm{Hg}$ contained in these dietary supplements, which could exceed the acceptable standard. The standards defined by different international organizations presented discrepancies in what concerns the listing of elements and compliance limits for each element. The World Health Organization (WHO) guidelines proposed $\mathrm{Pb}$ permissible levels $\left(10 \mu \mathrm{g} \cdot \mathrm{g}^{-1}\right)$ in medicinal raw plant materials and dietary supplements [13], whereas, for plant-based food supplements, the European Commission set limits of $3 \mu \mathrm{g} \cdot \mathrm{g}^{-1}$ and $0.1 \mu \mathrm{g} \cdot \mathrm{g}^{-1}$ for $\mathrm{Pb}$ and $\mathrm{Hg}$, respectively [14]. The United States Pharmacopeia (USP) recommended permissible limits (in $\mu \mathrm{g} \cdot \mathrm{g}^{-1}$ ) for $\mathrm{Pb}(0.5)$, As (0.15), and $\mathrm{Hg}(1.5)$ in dietary supplements $[15,16]$. Besides, the growing interest, popularity, and the lack of quantitative and qualitative research on the composition of supplements before being place into the market are important topics to attend [17].

The most common techniques used for the elemental analysis in dietary supplements include inductively coupled plasma optical emission spectrometry (ICP-OES) [18], inductively coupled plasma mass spectrometry (ICP-MS) $[3,19,20]$, wavelength dispersive-x-ray fluorescence spectrometry (WD-XRF) [16], scanning electron microscopyenergy dispersive $\mathrm{x}$-ray spectrometry (SEM-EDX), and ion chromatography (IC) [21]. However, to our knowledge, there is not any publication about the validation of an analytical method for heavy metals determination in dietary supplements by Total Reflection X-ray Fluorescence Spectroscopy (TXRF).

TXRF is a well-established analytical technique for multielement determination in various sample types, especially liquids and powdered microsamples. The $\mathrm{x}$-ray emitted in the TXRF is characteristic of each individual element and its intensities are proportional to their concentrations in the sample [22]. The incoming radiation is incident on the sample at less than the critical angle and is totally reflected; this is one difference with the XRF technique. Advantages include the element and its concentration being unaffected by matrix effects, its low sensitivity (ppb), requiring small amounts of sample ( $\mu \mathrm{g}$ or $\mu \mathrm{L})$, the use of small quantities of reagents, and not utilizing argon or nitrogen gases. The low background levels result in improved LODs and even 2 pg may be detected for a variety of elements with a counting time of $1,000 \mathrm{~s}$ [23-25]. Actually, the development and commercialization of TXRF instrumentation, which offers simple operations with a low-cost compact design, have promoted its application in many different fields [24].

In view of these premises, the aim of this work was the validation and application of a simple and accurate methodology to determine the content of $\mathrm{Pb}, \mathrm{As}, \mathrm{Cr}$, and $\mathrm{Hg}$ in dietary supplements by TXRF. Also, there were two research purposes, the first being to contribute to the risk assessment analysis regarding the consumption of dietary supplements and the second being to propose the TXRF technique as a powerful tool for quality standardization and control of both raw material and finished product.

\section{Materials and Methods}

2.1. Reagents and Standard Solutions. The concentrated nitric acid $\left(\mathrm{HNO}_{3}, 69 \% \mathrm{w} / \mathrm{w}\right)$, ethylenediaminetetraacetic acid (EDTA, 99.4-100.6\% w/w), hydrochloric acid $(\mathrm{HCl}$, $36.5-38 \% \mathrm{w} / \mathrm{w})$, and hydrogen peroxide $\left(\mathrm{H}_{2} \mathrm{O}_{2}, 30 \% \mathrm{w} / \mathrm{w}\right)$ were obtained from J.T. Baker (Mexico). ICP standard stock solutions contained $1000 \mathrm{mg} \cdot \mathrm{L}^{-1}$ of $\mathrm{Cr}$, As, and $\mathrm{Hg}$ which were purchased from Cresent Chemical Co., Inc. (Mexico). 
The $\mathrm{Pb}$ and $\mathrm{Ga}$ standard solutions were acquired from Sigma Aldrich (Mexico). Millipore-Q water (Milli-Q plus, $18.2 \mathrm{M} \Omega \cdot \mathrm{cm}^{-1}$ ) was used for standard and reagent preparations.

Individual single-element stock solutions containing $1000 \mathrm{mg} \cdot \mathrm{L}^{-1} \mathrm{~Pb}, \mathrm{As}, \mathrm{Cr}, \mathrm{Hg}$, and $\mathrm{Ga}$ were used as calibrations standards. Gallium was employed as an internal standard (IS) to improve the precision of quantitative analysis. For each element, six different known concentrations were prepared into $10 \mathrm{~mL}$ volumetric flasks and filled to the mark with $0.31 \mathrm{~mol} \cdot \mathrm{L}^{-1}$ of $\mathrm{HNO}_{3}$ y $10 \mu \mathrm{g} \cdot \mathrm{L}^{-1}$ of $\mathrm{Ga}$ (IS) solution. For $\mathrm{Hg}$ analysis, was utilized a dilute solution which contains $0.01 \mathrm{~mol} \cdot \mathrm{L}^{-1}$ of $\mathrm{HNO}_{3}, 0.01 \mathrm{~mol} \cdot \mathrm{L}^{-1}$ of EDTA, and $10 \mu \mathrm{g} \cdot \mathrm{L}^{-1}$ of $\mathrm{Ga}$. All glassware was kept overnight in $\mathrm{HNO}_{3}(10 \% \mathrm{v} / \mathrm{v})$ and rinsed several times with Millipore-Q water before its use to avoid cross-contamination.

2.2. Dietary Supplement Samples' Pretreatment. Different mixtures have been reported for the digestion procedure of dietary supplements. The most common compounds were the concentrated $\mathrm{HNO}_{3}$ [19], mixtures of $\mathrm{HNO}_{3}+\mathrm{HCl}$, and concentrated $\mathrm{HNO}_{3}+\mathrm{H}_{2} \mathrm{O}_{2}[3,20]$. The present work utilized a digestion procedure using concentrated $\mathrm{HNO}_{3}+\mathrm{HCl}+\mathrm{H}_{2} \mathrm{O}_{2}$ for the determination of $\mathrm{Pb}, \mathrm{As}, \mathrm{Cr}$, and $\mathrm{Hg}$ in six dietary supplements $[2,24]$.

Four dietary supplements, fat burner (A-01), laxative (A02), tejocote root (A-03), and Omega 6, 12 oil (A-04), were randomly collected from local Mexican suppliers. The selection criterion was based on high consumption and popularity in the treatment of chronic diseases (diabetes, high blood pressure, cancer, and obesity). The composition of all dietary supplements includes organic (carbohydrates, proteins, lipids, and vitamins) and inorganic compounds ( $\mathrm{Zn}, \mathrm{Cu}, \mathrm{Fe}, \mathrm{Ca}$, among others). For confidentiality reasons, the studied products shall not be identified.

The digestion procedure consisted of weighing approximately $0.020-0.050 \mathrm{~g}$ of each sample in polypropylene tubes. Then, $5 \mathrm{~mL}$ of $\mathrm{H}_{2} \mathrm{O}$ and $1 \mathrm{~mL}$ nitric acid concentrated solutions were added into glass testing tubes. Reagents and sample mixtures were allowed to stand for 15 minutes. Subsequently, $100 \mu \mathrm{L}$ of $\mathrm{H}_{2} \mathrm{O}_{2}, 485 \mu \mathrm{L}$ of concentrated $\mathrm{HNO}_{3}$, and $100 \mu \mathrm{L}$ of concentrated $\mathrm{HCl}$ were incorporated into tubes, which were covered with their respective stopper. A vortex was used to shake the samples in the testing tubes, which were then placed into a bathwater at $80^{\circ} \mathrm{C}$ for eight hours. After acid digestion, samples were filtered. Finally, samples were prepared into $25 \mathrm{~mL}$ volumetric flasks and filled to the mark with $0.31 \mathrm{~mol} \cdot \mathrm{L}^{-1}$ of $\mathrm{HNO}_{3}$ and $10 \mu \mathrm{g} \cdot \mathrm{L}^{-1}$ of $\mathrm{Ga}$ (IS) solution. For $\mathrm{Hg}$ analysis, a dilute solution was utilized which contains $0.01 \mathrm{~mol} \cdot \mathrm{L}^{-1}$ of $\mathrm{HNO}_{3}, 0.01 \mathrm{~mol} \cdot \mathrm{L}^{-1}$ of EDTA, and $10 \mu \mathrm{g} \cdot \mathrm{L}^{-1}$ of Ga. Blank samples were made to identify any possible source of contamination. Analyses were carried out in triplicate, and analytical blanks were prepared by following the same procedure used for the samples.

2.2.1. Analysis of Certified Reference Material. The USP mentioned some names of plants to develop standard mixtures that can be used in validation studies [15].
However, dietary supplements are usually made into different presentations, including powders, tablets, capsules, energy bars, liquids, and oils, among others [2], which implies a wide variety of matrices. This is because it is difficult to find certified reference materials, with the validation purpose. However, a BCR-610 (groundwater, CRM) was analyzed, adjusting the $\mathrm{HNO}_{3}$ concentration to $0.30 \mathrm{~mol} \mathrm{~L}^{-1}$ and added Ga as IS, without any prior digestion procedure. Samples were examined in triplicate by the TXRF_1 method.

\subsubsection{Intercomparison Studies between TXRF and ICP-OES.} All chemicals utilized were of analytical reagent grade. Hydrogen peroxide $\left(\mathrm{H}_{2} \mathrm{O}_{2}, 30 \% \mathrm{w} / \mathrm{w}\right)$ and nitric acid (65\% $\mathrm{w} / \mathrm{w}$ ) were obtained from Scharlau (Barcelona, Spain) as well as standard solutions of $\mathrm{As}, \mathrm{Cr}$, and $\mathrm{Pb}\left(1000 \mathrm{mg} \cdot \mathrm{L}^{-1}\right.$ in $2 \%$ of $\mathrm{HNO}_{3}$ ). Two samples (A-05 and A-06) were acquired from local Spain suppliers and employed for the intercomparison studies between TXRF and ICP-OES methods. The purpose was an estimate of the accuracy in the measurements of both methods. Student's $t$-test was utilized to find significant differences in the metal determinations.

According to its label, the A-05 sample is a dietary supplement utilized for the organism detoxification, while the A-06 (Fat Burner) is used to increase acutely fat metabolism and for the loss of weight. Both samples were weighed ( $0.5 \mathrm{~g}$ approximately) into a microwave Teflon vessel, to which $1 \mathrm{~mL}$ of $\mathrm{H}_{2} \mathrm{O}_{2}, 1 \mathrm{~mL}$ of $\mathrm{HCl}$, and $3 \mathrm{~mL}$ of $\mathrm{HNO}_{3}$ were added. After digestion, they diluted with $25 \mathrm{~mL}$ of water and analyzed by ICP-OES (Optimal 5300 DV PerkinElmer Inc.). In the TXRF method, A-05 and A-06 samples were pretreated by following the procedure indicated in Section 2.2.

2.3. Instrumentation and Experimental Procedure. The TXRF measurements were performed with a commercial S2 PICOFOX TXRF spectrometer (Bruker AXS Microanalysis $\mathrm{GmbH}$, Berlin, Germany), equipped with either a molybdenum (Mo) $\mathrm{x}$-ray tube operated at $600 \mu \mathrm{A}$ and $50 \mathrm{kV}$. The automatic sample changer (holder) allows up to 25 sample carriers to be loaded and analyzed. The software used in the instrument control, data collection, and data analysis was Spectra PICOFOX ${ }^{\circledR} 7$. The spectral lines utilized: $\mathrm{L}_{-\alpha}$ $10.5 \mathrm{KeV}, \mathrm{K}_{-\alpha} 5.4 \mathrm{KeV}, \mathrm{L}_{-\alpha} 9.2 \mathrm{KeV}, \mathrm{K}_{-\alpha} 10.5 \mathrm{KeV} y$, and $\mathrm{L}_{-\alpha}$ $10 \mathrm{KeV}$, for $\mathrm{Pb}, \mathrm{Cr}, \mathrm{Ga}$, As, and $\mathrm{Hg}$, respectively. Sample carriers and glassware were subjected to a strict cleaning protocol. The experimental procedure applied was that reported by Beltrán and Cols. [24].

2.4. Design of the Experiments. A response surface methodology involves several experimental techniques for the evaluation of the relationship between a group of controlled experimental factors and measured responses based on one or more criteria. Besides, it can be used to estimate the effect of individual parameters, the interaction of variables, and the optimum conditions for responses [17]. A central composite 
design (CCD) was used to investigate the impact of the selected parameters on the TXRF measurements.

The $\mathrm{HNO}_{3}$ concentration $\left(\mathrm{mol} \cdot \mathrm{L}^{-1}\right)$, EDTA concentration $\left(\mathrm{mol} \cdot \mathrm{L}^{-1}\right)$, and sample-reading time (s) were selected as the independent variables, while analytical signals $(\mathrm{Pb}, \mathrm{As}, \mathrm{Cr}$, and $\mathrm{Hg}$ ) were considered as the response (dependent variables). The independent variables vary between the lowest level of $-l$, center level 0 , and the highest level of $+l$. Then, their studied ranges were as follows; $\mathrm{HNO}_{3}$ concentration $\left(0.01-1 \mathrm{~mol} \cdot \mathrm{L}^{-1}\right)$, EDTA concentration $\left(0-0.1 \mathrm{~mol} \mathrm{~L}^{-1}\right)$, and sample-reading time $(100-500 \mathrm{~s})$. The range of independent variables was based on preliminary experiments and determined literature [24]. The experimental design points consist of the $2^{3}$ factorial points, six axial points, and six central points. Center points were used to determine the reproducibility of the data and the experimental error [17]. Results were examined by the software Minitab ${ }^{\circledR} 17$. Twenty experiments were performed to establish the optimal conditions utilizing the minimum reagents concentration and lower reading time.

2.5. Figures of Merit. Figures of merit considered in this work were (the linearity and range, limit of detection, limit of quantification, accuracy, and precision) according to the recommendations of IUPAC [26].

Calibration curves were prepared for each of the metals and running a range of concentration between 2 and $100 \mu \mathrm{g} \cdot \mathrm{L}^{-1}(\mathrm{~Pb}, \mathrm{As}$, and $\mathrm{Cr}$ ), and for $\mathrm{Hg}$ analysis in a range $5-100 \mu \mathrm{g} \cdot \mathrm{L}^{-1}$. It plotted on the $y$-axis (analyte peak area/Ga peak area) against the corresponding ones ( $x$-axis). The concentration of the analyzed samples was estimated by the assessment of the calibration curve data corresponding to each element: $m$ (the slope of the calibration curve) and $b$ (interception with the $y$-axis).

The LODs and LOQs were calculated as $3 \mathrm{~s} / \mathrm{m}$ and $10 \mathrm{~s} / \mathrm{m}$, respectively, where $s$ is the standard deviation of the analytical signal of ten blanks [26]. In addition, regression equations, determination coefficient $\left(R^{2}\right)$, analysis frequency $\left(\mathrm{h}^{-1}\right)$ were estimated. The precision was considered in terms of the intra-day repeatability and intra-day reproducibility by the use of $20 \mu \mathrm{g} \cdot \mathrm{L}^{-1}$ concentration level for all analytes and evaluated as the percentage of relative standard deviation (\% RSD).

2.6. Analysis of Real and Spiked Samples. The accuracy of the TXRF_DS_1 and TXRF_DS_2 methods were evaluated by the recovery percentage of heavy metals by known amount added to selected dietary supplements. Samples (A-01, A-02, A-03, and A-04) were spiked with a standard solution of $20 \mu \mathrm{g} \cdot \mathrm{L}^{-1} \mathrm{~Pb}, \mathrm{As}, \mathrm{Cr}$ and $\mathrm{Hg}$ during the digested process. Three replicates of each spiked samples were analyzed by TXRF under optimum conditions.

\section{Results and Discussion}

3.1. Optimization of the TXRF Variables. Table 1 shows the experimental design with 20 experiments with their analytical responses. The experiments were run randomly. The
ANOVA table showed a low fit for the tested models (Lineal, lineal + interactions, lineal + squares, and full quadratic). Thus, such as alternative, the optimal values of the variables that affected the proposed TXRF methods were obtained utilizing the desirability function. The function can be maximized by using a random starting point and then proceeding along the steepest slope up to a maximum. Starting from several points in the design space increases the chance of achieving the "best" maximum among all possible maxima of the function [27]. This mathematical model transforms each response into an individual desirability $\left(d_{\mathrm{i}}\right)$ value, coded from 0 (undesired response) to 1 (desired response). In this analysis, $\left(d_{\mathrm{i}}=1\right)$ corresponds to a desired response (maximum analytical signal for all elements), while $\left(d_{i}=0\right)$ represents a minimum analytical signal. Finally, the individual desirability of each analyte was combined into a single response, which means the overall desirability (CD) through the geometric mean [16]. The best experimental conditions were chosen according to the higher composite desirability (CD).

The analysis of data obtained in the experiment design included the four dependent variables and their response. In the first analysis, the $C D$ value was low (0.73). Probably, due to the $\mathrm{Hg}$ response had a different behavior than the other elements, that is the "EDTA concentration" variable was not significant for $\mathrm{Pb}, \mathrm{As}$ and $\mathrm{Cr}$ responses, but it was for $\mathrm{Hg}$. Therefore, a second analysis was carried out, excluding $\mathrm{Hg}$ data. In this case, the best local maximum was found to be at the sample-reading time of $500 \mathrm{~s}, 0.31 \mathrm{~mol} \mathrm{~L}^{-1} \mathrm{HNO}_{3}$, $0 \mathrm{~mol} \mathrm{~L}^{-1}$ EDTA, while the CD value was 0.9802 . However, looking for a compromise between the sensitivity of the technique and the lamp lifetime, the variable "samplereading time" was finally set to $401 \mathrm{~s}$, without the desirability value (0.9170) being affected (Figure 1). The desirability of 0.9170 indicates that the estimated function may express the desired conditions and the experimental model. Under these conditions, the method was called TXRF_DS_1.

The individual analysis for $\mathrm{Hg}$ analytical response showed that the best local maximum was found to be at the sample-reading time of $431 \mathrm{~s}, \mathrm{HNO}_{3}$ concentration of $0.01 \mathrm{~mol} \cdot \mathrm{L}^{-1}$, EDTA concentration of $0.01 \mathrm{~mol} \cdot \mathrm{L}^{-1}$, and CD value $=1$. In the same way, the sample-reading time variable was established in $401 \mathrm{~s}$ and the CD value was not affected (Figure 2). The Hg analysis method was called TXRF_DS_2.

3.2. Figures of Merit. Under the optimal conditions, the analytical performance of the proposed procedure was evaluating. Four calibration curves were built. Table 2 shows the linear calibration ranges and their respective determination coefficient $\left(R^{2}\right)$, LODs, LOQs, repeatability, and reproducibility for all analyses using TXRF_DS_1 and TXRF_DS_2 methods. The calibration plots are depicted in Figure 3.

The limit of detection (LOD) is the lowest concentration that can be detected, but not necessarily quantified. Detection limits for $\mathrm{Pb}, \mathrm{As}, \mathrm{Cr}$, and $\mathrm{Hg}$ were lower than LODs obtained with an ICP-OES method for the quantitative analysis of toxic elements in some dietary supplements and 
TABLE 1: Experimental conditions and values obtained through the CCD.

\begin{tabular}{|c|c|c|c|c|c|c|c|}
\hline \multirow[b]{2}{*}{ Runs no. } & \multicolumn{3}{|c|}{ Independent variables } & \multicolumn{4}{|c|}{ Analytical signals $(\mathrm{CPS})^{\mathrm{a}}$} \\
\hline & EDTA $\mathrm{mol} \cdot \mathrm{L}^{-1}$ & Time (s) & $\mathrm{HNO}_{3} \mathrm{~mol} \cdot \mathrm{L}^{-1}$ & $\mathrm{Cr}$ & As & $\mathrm{Pb}$ & $\mathrm{Hg}$ \\
\hline 1 & 0.005 & 300 & 0.505 & 680.3 & 2260.3 & 884 & 830 \\
\hline 2 & 0.005 & 300 & 0.505 & 756.3 & 1870.7 & 884 & 830 \\
\hline 3 & 0.005 & 300 & 0.010 & 335.5 & 2230.3 & 1104 & 883.5 \\
\hline 4 & 0.010 & 100 & 1 & 458.5 & 709 & 247.3 & 198 \\
\hline 5 & 0.010 & 500 & 1 & 937 & 3377 & 1194.7 & 883.3 \\
\hline 6 & 0.010 & 300 & 0.505 & 954 & 3741.7 & 1450.7 & 1343 \\
\hline 7 & 0 & 300 & 0.505 & 978.3 & 3371.7 & 1905.7 & 204 \\
\hline 8 & 0.005 & 100 & 0.505 & 199.3 & 768.7 & 395 & 126.3 \\
\hline 9 & 0 & 500 & 0.010 & 1093 & 4033.7 & 2539 & 238.3 \\
\hline 10 & 0.005 & 300 & 1 & 901 & 3036.5 & 1168 & 589 \\
\hline 11 & 0 & 100 & 1 & 291.7 & 751.7 & 464 & 189 \\
\hline 12 & 0.010 & 100 & 0.010 & 222.7 & 872.7 & 210 & 212 \\
\hline 13 & 0.005 & 300 & 0.505 & 680.3 & 2260.3 & 884 & 830 \\
\hline 14 & 0.005 & 300 & 0.505 & 756.3 & 1870.7 & 847 & 830 \\
\hline 15 & 0 & 100 & 0.010 & 402.7 & 1210.3 & 623.3 & 97 \\
\hline 16 & 0.005 & 500 & 0.505 & 878 & 3196.5 & 1256.5 & 597 \\
\hline 17 & 0.010 & 500 & 0.010 & 954 & 3741.7 & 1450.7 & 1343 \\
\hline 18 & 0 & 500 & 1 & 1203 & 3782 & 2303.5 & 232 \\
\hline 19 & 0.005 & 300 & 0.505 & 761.3 & 2239 & 884 & 830 \\
\hline 20 & 0.005 & 300 & 0.505 & 884 & 2313 & 884 & 830 \\
\hline
\end{tabular}

${ }^{\mathrm{a}}$ Counts per seconds, CPS.

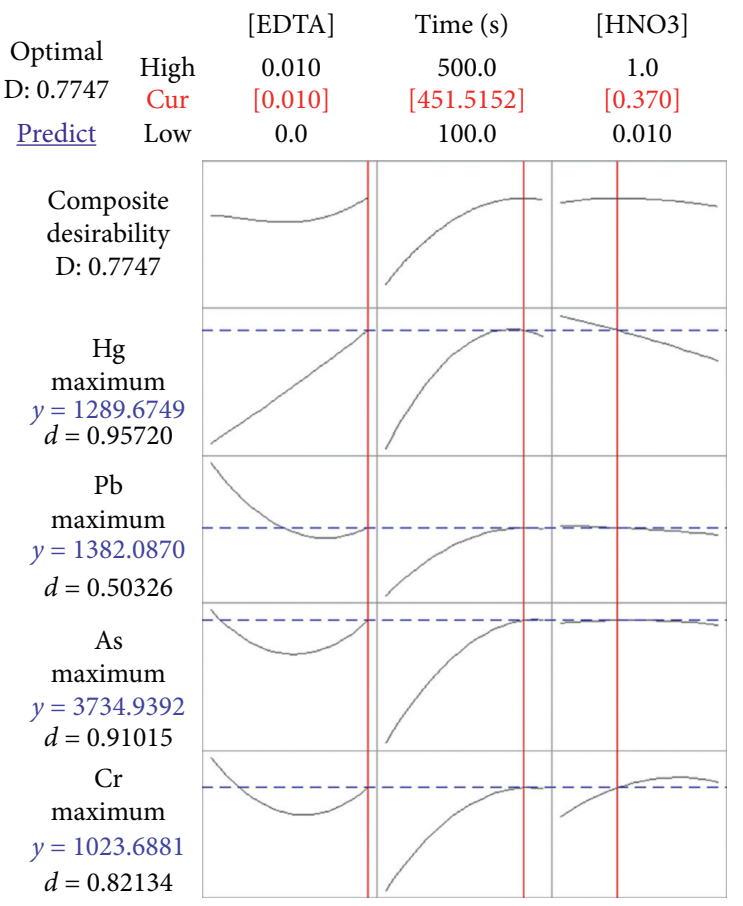

(a)

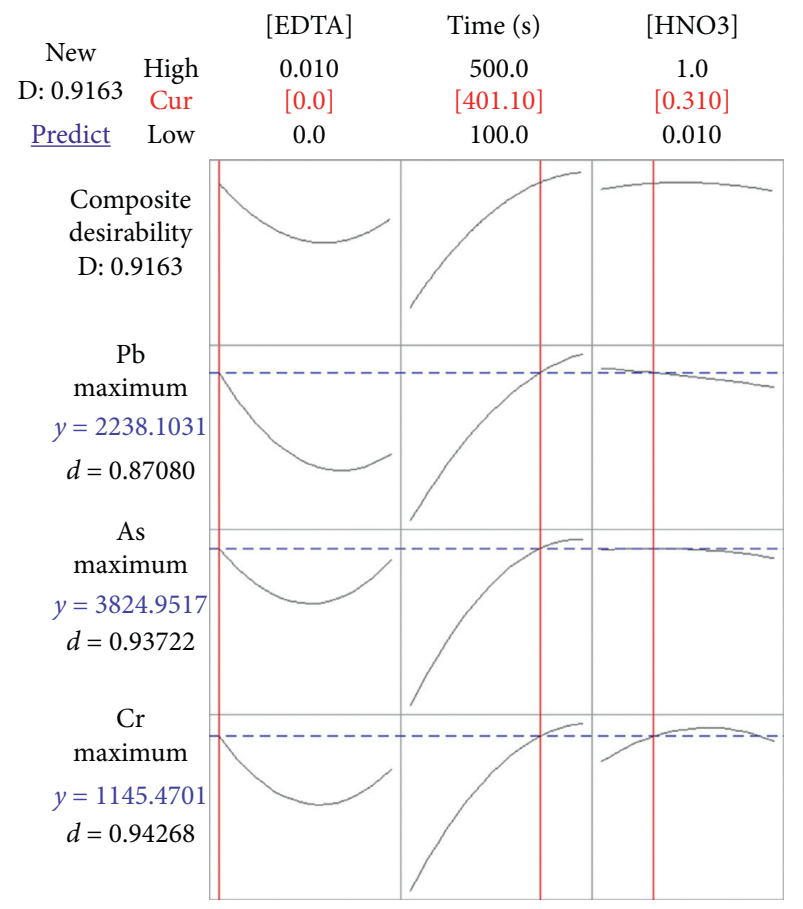

(b)

Figure 1: Response optimization plots. (a) First analysis with analytical responses $\mathrm{Pb}, \mathrm{Cr}$, As, and $\mathrm{Hg}(\mathrm{CD}=0.7774)$. (b) Second analysis without $\mathrm{Hg}$ analytical response $(\mathrm{CD}=0.9163)$.

diet products [18]. However, the excellent analytical sensitivity that ICP-MS allows is indisputable. Table 3 shows other methods that had better LODs than those achieved in proposed TXRF methods [3, 19]. Nevertheless, these methods utilized a larger amount of samples and reagents for digestion procedures in comparison with TXRF_DS_1 and TXRF_DS_2 methods. Besides, our methods use a final dilution of samples between 10 and $25 \mathrm{~mL}$ (4-fold lower than other proposed methods). In addition, a sample volume of $10 \mu \mathrm{L}$ was required, which contributes to the minimization of residues. The TXRF neither requires an argon gas nor hydride generation system. Moreover, all 


$\begin{array}{ccccc} & & \text { [EDTA }] & \text { Time }(\mathrm{s}) & \text { [HNO3] } \\ \text { Optimal } & \text { High } & 0.010 & 500.0 & 1.0 \\ \text { D: } 1.000 & \text { Cur } & {[0.010]} & {[431.3131]} & {[0.010]} \\ \text { Predict } & \text { Low } & 0.0 & 100.0 & 0.010\end{array}$

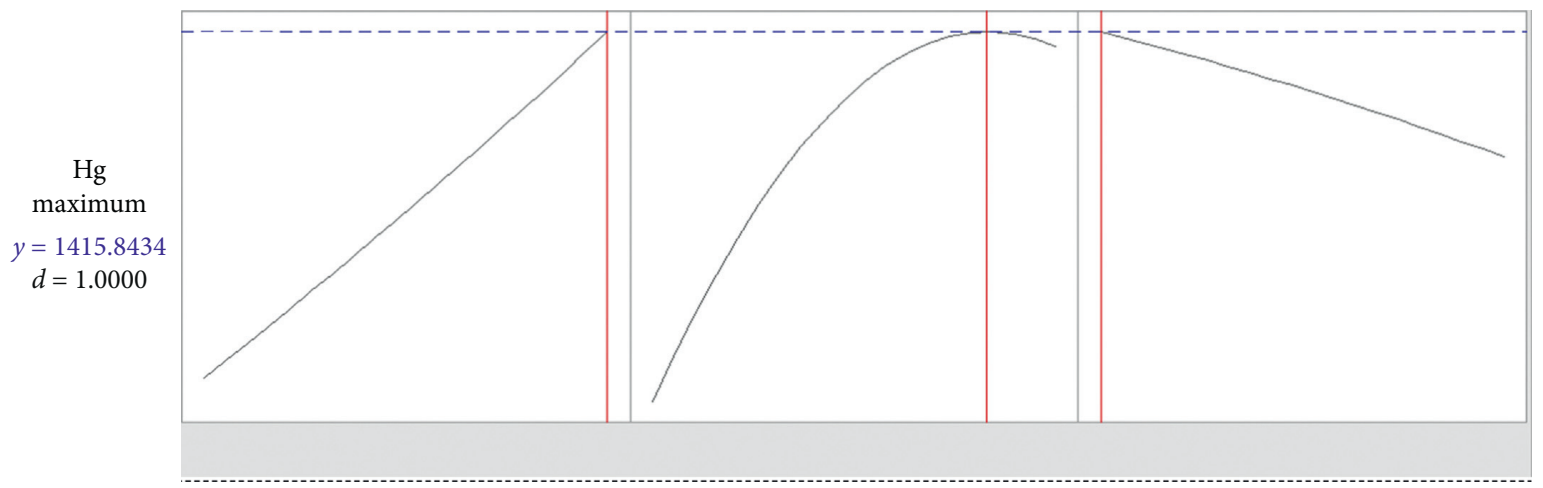

(a)

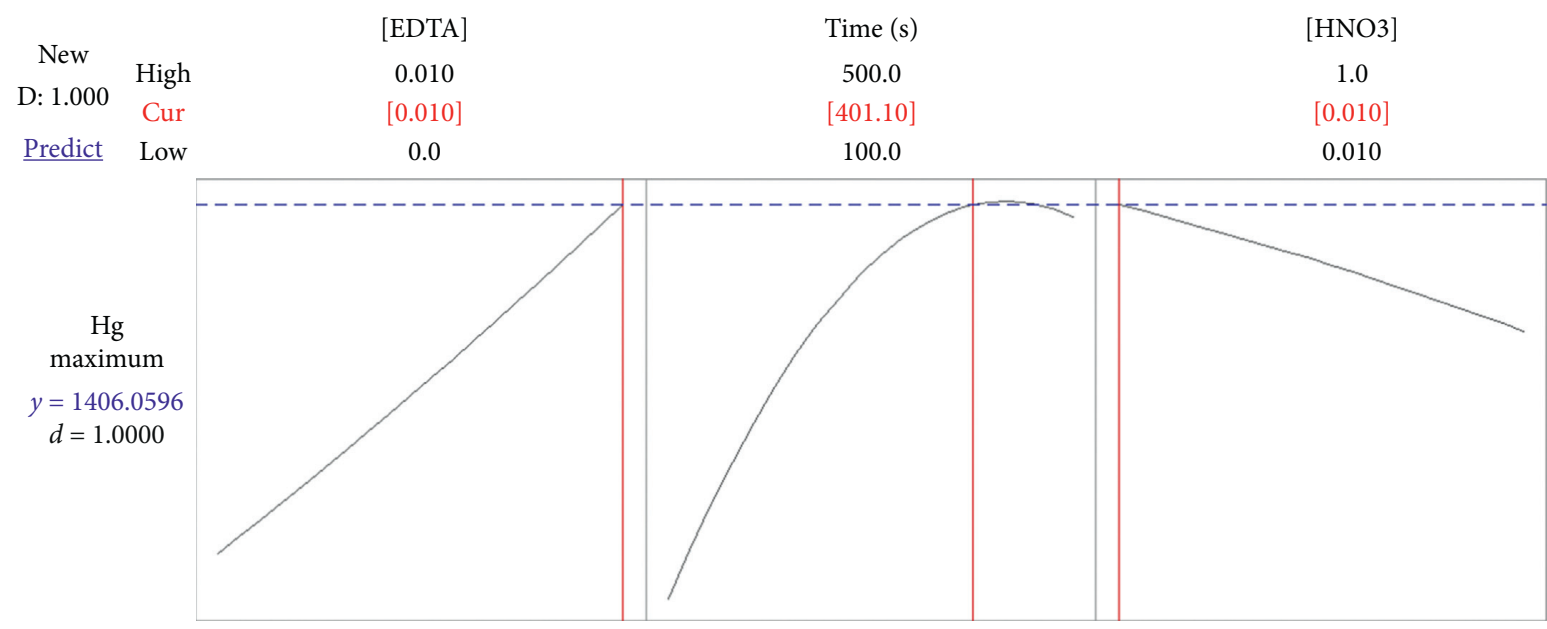

(b)

FIgURE 2: Response optimization plots. (a) First analysis with $\mathrm{Hg}$ analytical response $\mathrm{Hg}(\mathrm{CD}=1)$. (b) Second analysis modifying the reading time $(\mathrm{CD}=1)$.

TABLE 2: Figures of merit of TXRF methods.

\begin{tabular}{lccccc}
\hline Element & LOD $\mu \mathrm{g} \cdot \mathrm{L}^{-1}$ & LOQ $\mu \mathrm{g} \cdot \mathrm{L}^{-1}$ & Repeatability \% RSD & Reproducibility \%RSD & Lineal range $\mu \mathrm{g} \cdot \mathrm{L}^{-1}$ \\
\hline $\mathrm{Pb}^{a}$ & 0.59 & 1.95 & 3.31 & 3.26 & $1.95-100$ \\
$\mathrm{As}^{a}$ & 0.41 & 1.35 & 1.59 & 1.96 & 0.9999 \\
$\mathrm{Cr}^{a}$ & 0.57 & 1.90 & 5.11 & 5.27 & 0.9999 \\
$\mathrm{Hg}^{b}$ & 0.75 & 2.50 & 1.71 & 4.77 & $1.90-100$ \\
\hline
\end{tabular}

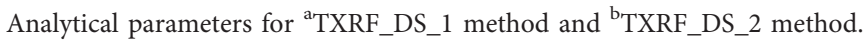

LODs were lower than levels suggested by international organizations (WHO and US Pharmacopeia) [13, 15].

The LOQs were calculated and produced a peak with ten times the signal-noise ratio for $\mathrm{Pb}, \mathrm{As}, \mathrm{Cr}$, and $\mathrm{Hg}$, respectively, and were in the range of $1.35-2.50 \mu \mathrm{g} \cdot \mathrm{L}^{-1}$.

The precision under intraday repeatability and intraday reproducibility was assessed as the relative standard deviation (\% RSD). The intraday repeatability was calculated based on five consecutive measurements of a standard solution $\left(20 \mu \mathrm{g} \cdot \mathrm{L}^{-1}\right)$ using the same measurement procedure and the same operating conditions. The intraday reproducibility can be obtained with stated precision by five consecutive measurements of $\left(20 \mu \mathrm{g} \cdot \mathrm{L}^{-1}\right)$ standard solution in a different analysis day. For all elements retained in the analysis, \% RSD values are lower than $20 \%$, as recommended by the US Pharmacopeia [28]. Table 2 shows figures of merit for the proposed methods. The calibration curves achieved statistically satisfactory results $\left(R^{2}>0.999\right)$. The analysis frequency was nine samples per hour.

3.3. Analysis of Certified Reference Material. To complete the validation of the TXRF_DS_1 method, a BCR-610 certified reference material was analyzed for $\mathrm{Pb}$ and $\mathrm{As}$. The results 

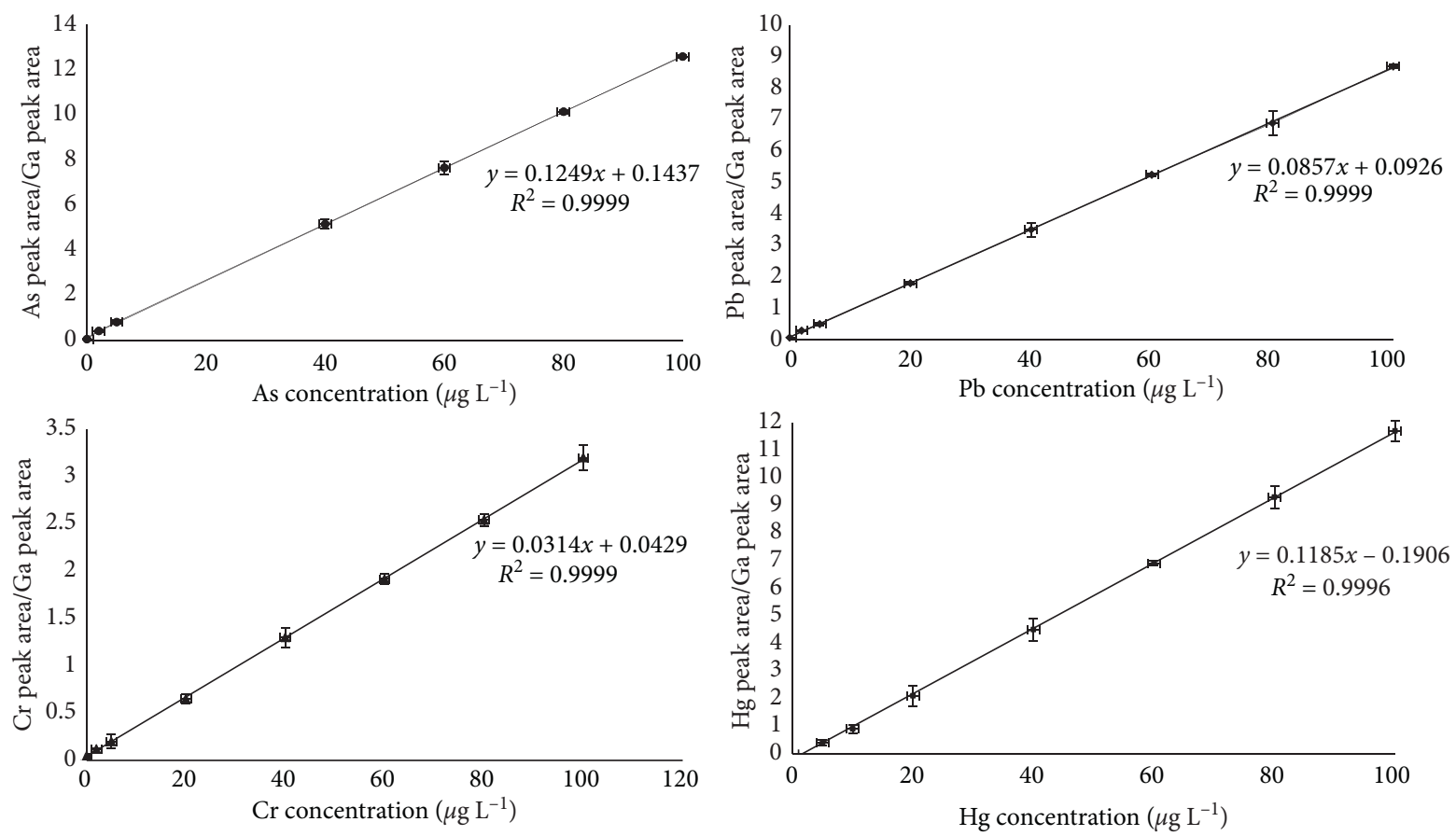

FIgURE 3: Calibration curves for As, Pb, and Cr. TXRF_DS_1 method optimal conditions: $0.31 \mathrm{~mol} \cdot \mathrm{L}^{-1}$ of $\mathrm{HNO}_{3}$ and $10 \mu \mathrm{g} \cdot \mathrm{L}^{-1}$ of Ga (IS) solution. Calibration curve for Hg under TXRF_DS_2 method optimal conditions: $0.01 \mathrm{~mol} \cdot \mathrm{L}^{-1}$ of $\mathrm{HNO}_{3}, 0.01 \mathrm{~mol} \cdot \mathrm{L}^{-1}$ of EDTA, and $10 \mu \mathrm{g} \cdot \mathrm{L}^{-1}$ of $\mathrm{Ga}$. The error bars represent the standard deviation $(n=3)$ for each point.

TABle 3: Comparison of methods for $\mathrm{Pb}, \mathrm{As}, \mathrm{Cr}$, and $\mathrm{Hg}$ determinations in dietary supplements.

\begin{tabular}{|c|c|c|c|c|c|c|c|}
\hline \multirow{2}{*}{ Analytical technique } & \multirow{2}{*}{ Digestion procedure $^{\mathrm{a}}$} & \multicolumn{4}{|c|}{ LODs $\left(\mu \mathrm{g} \cdot \mathrm{L}^{-1}\right)$} & \multirow{2}{*}{ Observations } & \multirow{2}{*}{ Ref. } \\
\hline & & $\mathrm{Pb}$ & As & $\mathrm{Cr}$ & $\mathrm{Hg}$ & & \\
\hline TXRF & $\begin{array}{c}0.020-0.050 \mathrm{~g} \\
485 \mu \mathrm{L} \mathrm{HNO} 3 \\
100 \mu \mathrm{L} \mathrm{HCl} \\
500 \mu \mathrm{L} \mathrm{H}_{2} \mathrm{O}_{2} \\
0.5 \mathrm{~g}^{\mathrm{a}}\end{array}$ & 0.59 & 0.41 & 0.57 & 0.75 & No requirement of argon gas; $10-25 \mathrm{~mL}^{\mathrm{b}}$ & Present work 2020 \\
\hline ICP-OES & $\begin{array}{c}9 \mathrm{~mL} \mathrm{HNO}_{3} \\
3 \mathrm{~mL} \mathrm{HCl}\end{array}$ & 5 & 5 & 2.5 & 1 & As and $\mathrm{Hg}$ analysis by $\mathrm{HG}$ & {$[18]$} \\
\hline ICP-MS & $\begin{array}{c}0.3^{-1} \mathrm{~g}^{\mathrm{a}} \\
3-5 \mathrm{~mL} \mathrm{HNO}_{3} \mathrm{HNO}_{3} \\
15 \mathrm{~g}^{\mathrm{a}}\end{array}$ & 0.20 & 0.004 & 0.011 & - & $100 \mathrm{~mL}^{\mathrm{b}}$ & {$[19]$} \\
\hline ICP-MS & $\begin{array}{c}7.5 \mathrm{~mL} \mathrm{HNO}_{3} \\
2.5 \mathrm{~mL} \mathrm{HCl}\end{array}$ & 0.002 & 0.010 & - & - & $100 \mathrm{~mL}^{\mathrm{b}}$ & {$[3]$} \\
\hline
\end{tabular}

${ }^{a}$ Grams of sample; ${ }^{b}$ final dilution volume of samples after digestion procedure.

were obtained by three replicates $(n=3)$ and expressed as the means and their standard deviation. The $t$-test for the comparison of means revealed that there were no significant differences at a $95 \%$ confidence level between the values obtained $\left(7.85 \pm 0.04 \mu \mathrm{g} \cdot \mathrm{L}^{-1}\right.$ and $10.79 \pm 0.40 \mu \mathrm{g} \cdot \mathrm{L}^{-1}$ for $\mathrm{Pb}$ and As, respectively) and the certified values $\left(7.78 \pm 0.13 \mu \mathrm{g} \cdot \mathrm{L}^{-1}\right.$ for $\mathrm{Pb}$ and $10.40 \pm 0.25 \mu \mathrm{g} \cdot \mathrm{L}^{-1}$ for As).

3.4. Intercomparison Studies between TXRF and ICP-OES. Two dietary supplements were analyzed in the intercomparison study between TXRF and ICP-OES methods (Table 4). Student's $t$-tests were performed to compare the experimental data obtained between the TXRF-DS_1 method and ICP-OES method. Sample pretreatment was carried out according to Section 2.2.2. First, in the A-05 sample, the $\mathrm{Pb}$ concentrations were in agreement in both methods; in the case of $\mathrm{Cr}$ and As determinations, it was not possible to establish a comparison, because some values were below ICP-OES LOQ. The results found for $\mathrm{Pb}$ and $\mathrm{Cr}$ determinations in the A-06 sample showed that there were no significant differences at a confidence level of $95 \%$ for $n=3$. However, As was not detected by ICP-OES. The results demonstrated that the accuracy of the TXRF_DS_1 method is acceptable.

3.5. Analysis of Real and Spiked Samples. The developed procedures were applied for the determination of $\mathrm{Pb}, \mathrm{As}$, $\mathrm{Cr}$, and $\mathrm{Hg}$ in real and spiked dietary supplements. 
TABLE 4: Intercomparison studies between TXRF and ICP-OES methods.

\begin{tabular}{lccc}
\hline \multirow{2}{*}{ Sample } & \multicolumn{3}{c}{ Methods comparison $^{\mathrm{a}}$} \\
& Element & ICP-OES $\left(\mu \mathrm{g} \cdot \mathrm{L}^{-1}\right)$ & TXRF-DS-1 $\left(\mu \mathrm{g} \cdot \mathrm{L}^{-1}\right)$ \\
\hline \multirow{4}{*}{ A5 } & $\mathrm{Pb}$ & $0.57 \pm 0.32$ & $0.54 \pm 0.16$ \\
& $\mathrm{Cr}$ & $\leq \mathrm{LOQ}$ & $\leq \mathrm{LOQ}$ \\
& $\mathrm{As}$ & $\leq \mathrm{LOQ}$ & $0.16 \pm 0.030$ \\
$\mathrm{~A}-06$ & $\mathrm{~Pb}$ & $0.70 \pm 0.36$ & $0.25 \pm 0.023$ \\
& $\mathrm{Cr}$ & $57.56 \pm 1.50$ & $58.61 \pm 1.54$ \\
& $\mathrm{As}$ & $\leq \mathrm{LOQ}$ & $0.38 \pm 0.070$ \\
\hline
\end{tabular}

${ }^{\text {a }}$ Results are expressed as the mean value $\pm s(n=3)$. s, standard deviation.

TABLE 5: Results of the recovery study in the dietary supplements.

\begin{tabular}{lcccc}
\hline Sample $^{\mathrm{a}}$ & Metal & $\begin{array}{c}\mathrm{b}^{\mathrm{b}} \text { Analyzed sample } \\
\mu \mathrm{g} \cdot \mathrm{L}^{-1}\end{array}$ & $\begin{array}{c}\mathrm{b}^{\mathrm{b}} \text { Spiked sample } \\
\mu \mathrm{g} \cdot \mathrm{L}^{-1}\end{array}$ & $\begin{array}{c}\% \\
\text { recovery }\end{array}$ \\
\hline \multirow{3}{*}{$\mathrm{A}-01$} & $\mathrm{~Pb}$ & $2.64 \pm 0.17$ & $22.92 \pm 0.59$ & 101 \\
& $\mathrm{As}$ & $1.51 \pm 0.059$ & $22.47 \pm 1.13$ & 105 \\
& $\mathrm{Cr}$ & $31.61 \pm 0.46$ & $52.15 \pm 0.45$ & 103 \\
$\mathrm{~A}-02$ & $\mathrm{~Pb}$ & $1.77 \pm 0.11$ & $19.88 \pm 0.078$ & 91 \\
& $\mathrm{As}$ & $0.45 \pm 0.015$ & $22.17 \pm 0.45$ & 108 \\
$\mathrm{~A}-03^{\mathrm{c}}$ & $\mathrm{Cr}$ & $18.63 \pm 0.31$ & $39.65 \pm 0.32$ & 105 \\
$\mathrm{~A}-04^{\mathrm{c}}$ & $\mathrm{Hg}$ & $0.37 \pm 0.30$ & $20.15 \pm 0.10$ & 99 \\
\hline
\end{tabular}

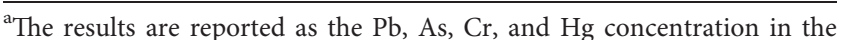
analyzed solutions. ${ }^{\mathrm{b}}$ Results are expressed as the mean value $\pm s(n=3)$. $s$, standard deviation. ${ }^{\mathrm{c}}$ Samples analyzed with TXRF_DS_2.

Sample pretreatment was carried out according to Section 2.2. Concentrations of the target analytes in samples were obtained by using calibration curves and are shown in Table 5. The obtained recoveries of $\mathrm{Pb}, \mathrm{As}$, and $\mathrm{Cr}$ in $\mathrm{A}-01$ and A-02 were ranging from $91 \%$ to $105 \%$. The $\mathrm{Hg}$ concentrations in these samples were less than the proposed LOD. These samples were analyzed by the TXRF_DS_1 method. The analysis recoveries of $\mathrm{Hg}$ were probed once more in the two samples A- 03 and A- 04 by the method TXRF_DS_2. The high recovery values indicated the absence of analyte loss during the sample preparation step and that sensitivity was not influenced by the dietary supplements matrix.

Sample concentrations were expressed as $\mu \mathrm{g}$ of heavy metals per gram of sample. For sample A_01, we obtained $1.12 \mu \mathrm{g} \cdot \mathrm{g}^{-1} \mathrm{~Pb}, 0.65 \mu \mathrm{g} \cdot \mathrm{g}^{-1} \mathrm{As}$, and $13.62 \mu \mathrm{g} \cdot \mathrm{g}^{-1} \mathrm{Cr}$. On the other hand, sample A_02 contained 1.32, 0.37, and $13.69 \mu \mathrm{g} \cdot \mathrm{g}^{-1}$ of $\mathrm{Pb}, \mathrm{As}$, and $\mathrm{Cr}$, respectively. Mercury was not detected in these two samples. For samples A_03 and A_04, the $\mathrm{Hg}$ contents were $0.42 \mu \mathrm{g} \cdot \mathrm{g}^{-1}$ and $0.12 \mu \mathrm{g} \cdot \mathrm{g}^{-1}$. These samples were analyzed with the TXRF_DS_2 method, exclusively for $\mathrm{Hg}$.

The results show that methods TXRF_DS_1 and TXRF_DS_2 are suitable options to quantify without any problem to heavy metals at trace levels, even below the maximum permissible limits imposed by international standards [13-16]. The TXRF technique is presented as a useful tool for monitoring heavy metals in food supplements, through which the quality of these products can be guaranteed before going to market and consumers ingest them.

\section{Conclusions}

The scientific and regulatory challenges in terms of the quality, safety, and efficacy of dietary supplements are common to all countries as the marketplace for them becomes increasingly global. In this study, two methods for quantitative analysis for the determination of toxic metals $(\mathrm{Pb}, \mathrm{As}, \mathrm{Cr}$, and $\mathrm{Hg}$ ) were developed, validated, and applied for the analysis of dietary supplements samples. It utilized a central composite design and desirability function for the method validation. Results obtained as linearity, accuracy, precision, LODs, and LOQs were within satisfactory borders, because we recommend TXRF_DS_1 and TXRF_DS_2 methods for heavy metal determinations in dietary supplements at trace level. No significant differences were found in the inter-comparison studies between TXRF and ICP-OES methods. TXRF methods improve the economy of laboratories in the research centers, universities, and industry. As they are environmentally friendly since the consumption of samples and reagents is minimum, they do not use toxic reagents, and it is not necessary to use carrier gases. These characteristics allow their use in toxicological, environmental, biological, and food studies. Finally, this research proposes two methods for the standardization and control of the quality of both the raw material and the dietary supplement finished product before human consumption.

\section{Data Availability}

The data used to support the findings of this study are available from the corresponding author upon request.

\section{Conflicts of Interest}

All authors declare that they have no conflicts of interest.

\section{Acknowledgments}

Blanca G. Beltrán gratefully acknowledges financial support for research from the "Programa para el Desarrollo Profesional Docente (PRODEP UACH-PTC-367)" of the Autonomous University of Chihuahua. In addition, the authors extended acknowledgements to the Laboratory of Environmental Analytical Chemistry, University of the Balearic Islands, for allowing the partial realization of scientific research and a research stay.

\section{References}

[1] Food and Drug Administration, FDA 101: Dietary Supplements, Food and Drug Administration, Silver Spring, MD, USA, 2015.

[2] J. Marreno, R. Jiménez-Rebagliati, E. Leiva, A. Londonio, and P. Smichowski, "Inductively coupled plasma optical emission spectrometric determination of fifteen elements in dietaty supplements: are the concentration declared in the labels accurate?" Microchemical Journal, vol. 105, pp. 81-86, 2013.

[3] A. Bobaker, I. Alakili, S. Sarmani, N. Al-Ansari, and Z. Yaseen, "Determination and assessment of the toxic heavy metal elements abstracted from the traditional plant cosmetics and medical remedies: case study of libya," International Journal of 
Environmental Research and Public Health, vol. 16, pp. 1-14, 2019.

[4] J. G. Costa, B. Vidovic, N. Saraiva et al., "Contaminants: a dark side of food supplements?” Free Radical Research, vol. 53, no. 1, pp. 1113-1135, 2019.

[5] I. Baer, B. De la Calle, S. Lane et al., "IMPE-28: total arsenic, cadmium, lead and mercury in food supplements: interlaboratory comparison report," in JRC Scientific and Technical Reports, pp. 6-17, Publications Office of the European Union, Brussels, Belgium, 2009.

[6] J. S. Tsuji, E. T. Chang, P. R. Gentry, H. J. Clewell, P. Boffetta, and S. M. Cohen, "Dose-response for assessing the cancer risk of inorganic arsenic in drinking water: the scientific basis for use of a threshold approach," Critical Reviews in Toxicology, vol. 49, no. 1, pp. 36-84, 2019.

[7] Food and Drug Administration, "Lead in food, foodwares, and dietary supplements," 2020, http://www.fda.gov/food/ metals/lead-food-foodwares-and-dietary-supplements.

[8] B. Debnath, W. S. Singh, and K. Manna, "Sources and toxicological effects of lead on human, health," Indian Journal of Medical Specialities, vol. 10, pp. 66-71, 2019.

[9] H. Sun, J. Brocato, and M. Costa, "Oral chromium exposure and toxicity," Current Environmental Health Reports, vol. 2, no. 3, pp. 295-303, 2015.

[10] S. Wilbur, H. Abadin, M. Fay et al., "Toxicological profile for chromium," in Agency for Toxic Substances and Disease Registry (ATSDR), ATSDR Toxicological Profiles, Ed., pp. 50-89, SRC Inc., New York, NY, USA, 2012.

[11] N. M. Abdulla, B. Adam, I. Blair, and A. Oulhaj, "Heavy metal content of herbal health supplement products in Dubai- UAE: a cross-sectional study," BMC Complement Altern. Med, vol. 19, pp. 1-9, 2019.

[12] B. Brodziak-Dopierała, A. Fischer, W. Szczelina, and J. Stojko, "The content of mercury in herbal dietary supplements," Biological Trace Element Research, vol. 185, pp. 236-243, 2018.

[13] Word Health Organization, "Quality control methods for herbal materials," 2011, https://apps.who.int/iris/handle/ $10665 / 44479$.

[14] The commission of the European communities, "Commision regulation (EC) N 629/2018. Off," Journal of European Union, vol. 7, pp. 6-9, 2008.

[15] The United States Pharmacopeia Convention, Elemental Impurities-Limits. Second Supplement to USP 38 - NF 33, Charper 233 Official December 1, The United States Pharmacopeia, Rockville, MD, USA, 2017.

[16] F. C. Pinheiro, D. V. Babos, A. I. Barros, E. R. Pereira-Filho, and J. A. Nóbrega, "Microwave-assisted digestion using dilute nitric acid solution and investigation of calibration strategies for determination of $\mathrm{As}, \mathrm{Cd}, \mathrm{Hg}$ and $\mathrm{Pb}$ in dietary supplements using ICP-MS," Journal of Pharmaceutical and Biomedical Analysis, vol. 174, pp. 471-478, 2019.

[17] V. Javanbakht and S. M. Ghoreishi, "Application of response surface methodology for optimization of lead removal from an aqueous solution by a novel superparamagnetic nanocomposite," Adsorption Science \& Technology, vol. 35, no. 1-2, pp. 241-260, 2017.

[18] H. S. Canbay and M. Doğantürk, "Metals determination by microwave digestion ICP-oes of some dietary supplements and diet products in Turkey," Eurasian Journal of Analytical Chemistry, vol. 12, pp. 45-53, 2017.

[19] A. Łozak, K. Sołtyk, M. Kiljan, Z. Fijałek, and P. Ostapczuk, "Determination of selected trace elements in dietary supplements containing plant materials," Polish Journal of Food and Nutrition Sciences, vol. 62, pp. 97-102, 2012.
[20] S. Sudhir and R. P. Suryawanshi, "Quantitative analysis of toxic elements by ICP-MS in herbal tablets," Journal of Academia and Industrial Research, vol. 3, pp. 445-45, 2015.

[21] A. Filipiak-Szok, M. Kurzawa, and E. Szłyk, "Determination of toxic metals by ICP-MS in Asiatic and European medicinal plants and dietary supplements," Journal of Trace Elements in Medicine and Biology, vol. 30, pp. 54-58, 2015.

[22] J. Frederick, Y. X. Antosz, A. Diaz, and A. Jensen, "The use of total reflectance X-ray fluorescence (TXRF) for the determination of metals in the pharmaceutical industry," Journal of Pharmaceutical and Biomedical Analysis, vol. 62, pp. 17-22, 2012.

[23] P. Wobrauschek, "Total reflection $\mathrm{x}$-ray fluorescence analysisa review," X-Ray Spectrometry, vol. 36, no. 5, pp. 289-300, 2007.

[24] B. G. Beltrán, I. Martínez-Serrano, V. Ramos-Sanchez, D. Chávez-Flores, M. C. Nevárez-Rodríguez, and E. A. Suárez-Domínguez, "Development and validation of a new method for determination of $\mathrm{Pb}$ and $\mathrm{Cr}$ in marine organisms by total reflection X-ray fluorescence (TXRF) spectroscopy," Journal of Analytical Methods in Chemistry, vol. 2019, pp. 1-7, 2019.

[25] L. Borguese, F. Bilo, S. Federici et al., "Summary of ISO standard 20289: total reflection X-ray fluorescence analysis of water," Surface and Interface Analysis, vol. 52, pp. 119-123, 2020.

[26] J. A. Carter, A. I. Barros, J. A. Nóbrega, and G. L. Donati, "Traditional calibration methods in atomic spectrometry and new calibration strategies for inductively coupled plasma mass spectrometry," Front. Chem, vol. 6, p. 504, 2018.

[27] A. C. L. Batista, E. R. Villanueva, R. V. S. Amorim, M. T. Tavares, and G. M. Campos-Takaki, "Chromium (VI) ion adsorption features of chitosan film and its chitosan/ zeolite conjugate 13X filmfilm and its chitosan/zeolite conjugate 13X film," Molecules, vol. 16, no. 5, pp. 3569-3579, 2011.

[28] The United States Pharmacopeia Convention, General Chapter Elemental Impurities-Procedures: 2nd Supplement of USP 35-NF 30. Charper 232 Official December 1, The United States Pharmacopeia, Rockville, MD, USA, 2015. 